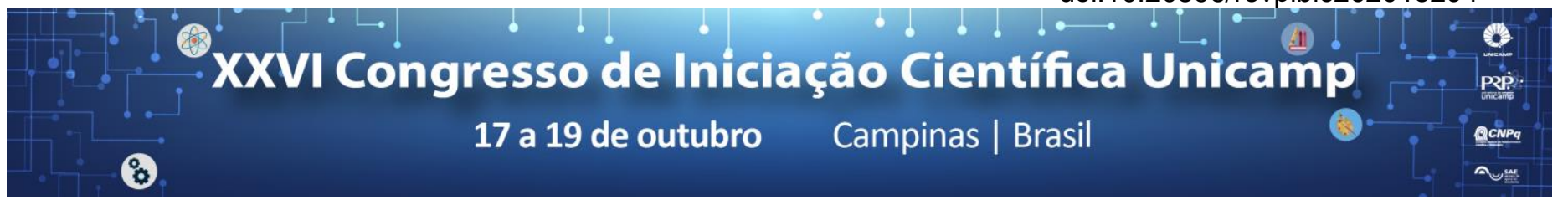

\title{
As contribuições de Anne Marie Chartier para a compreensão das práticas culturais escolares
}

\section{Carolina Salinas Piorini, Claudia Beatriz de Castro N. Ometto}

\begin{abstract}
Resumo
o objetivo deste estudo de Iniciação Científica foi sistematizar os conceitos de práticas culturais na perspectiva de Anne Marie Chartier a fim de relacioná-los com a discussão sobre as práticas cotidianas escolares. De natureza bibliográfica, o estudo levantou as principais obras e artigos da autora, publicados em português. Foram encontrados sete (7) textos de Anne-Marie Chartier e quatro (4) entrevistas. É possível afirmar que seus estudos contribuem para a valorização e importância da troca de experiências entre os professores, com o saber prático (saberes cotidianos) e os conhecedores de novos saberes teóricos em contextos de formação continuada.
\end{abstract}

\section{Palavras-chave:}

Formação de professores, Práticas escolares, Leitura e escrita.

\section{Introdução}

Este estudo de Iniciação científica vem apresentar os conceitos de práticas culturais na perspectiva de Anne-Marie Chartier a fim de relacioná-los com a discussão sobre as práticas cotidianas escolares de leitura e escrita, que contribuem para a formação de professores e leitores e para o trabalho com estudantes do Ensino Fundamental II e Médio.

\section{Resultados e Discussão}

A autora Anne-Marie Chartier enfatiza discussões sobre as práticas de escolarização, a fim de refletir, por meio da análise histórica, sobre os processos de ensino que envolviam a leitura e a escrita, atentando-se ao fracasso escolar, à demanda por novas práticas de leitura, incluindo o debate sobre a formação de leitores e o consumo cultural, problematizando o valor e o uso social do livro, além de debater a importância da troca de experiências entre professores experientes e recém formados, inferindo que os saberes científicos são indissociáveis dos saberes da ação.

A fim de fundamentar sua reflexão, a autora baseou-se em suas análises sobre os cadernos escolares encontrados referentes ao século XIX, que revelaram práticas pedagógicas e muito sobre a cultura escrita, destacando que a cultura escolar se transforma ao longo dos tempos modificando saberes e práticas (CHARTIER, 2007), visto que a experiência de leitura muda em função de novos contextos sociais.

Importante esclarecer que, ao longo de sua análise, Chartier reitera a importância da compreensão dos fatos de acordo com o seu tempo histórico, isto é, com o contexto cultural em que determinadas situações ocorreram, visto que a cultura escolar se transforma ao longo dos tempos modificando saberes e práticas, o que se pode ver nos trechos em que analisa os cadernos escolares. A autora tece uma crítica por afirmar que não se sabe, de fato, quais foram as reais práticas, mas que, a partir dos documentos encontrados constatou-se práticas baseadas na centralidade do professor, com a constante realização de cópia e reescrita a fins de memorização por parte dos alunos. No intuito de conhecer as práticas cotidianas buscou "[...] relacionar os cadernos às normas de seu tempo, tanto as escolares como as sociais e culturais" (CHARTIER, 2007, p.18), bem como os exercícios praticados na sala de aula.

\section{Conclusões}

A autora destaca temas que preocupam quem pensa e realiza a educação, preocupações recorrentes, tais como o fracasso escolar, estudado desde a escola republicana francesa. Também levanta as contribuições trazidas pela Escola de La Salle e as mudanças de uma educação baseada em leituras canônicas para o início de uma educação pautada na valorização de leituras de interesse do próprio aluno; a formação de professores, e suas contribuições por meio da valorização e da importância da troca de experiências entre os mesmos, com o saber prático (saberes cotidianos) e os conhecedores de novos saberes teóricos dos professores recém formados; a formação de professores-leitores e alunos-leitores, e acerca das práticas culturais que qualificam os leitores e o advento da tecnologia, inserindo-se, aos poucos, no contexto escolar.

\section{Agradecimentos}

Agradecimentos a minha orientadora Prof ${ }^{a} \mathrm{Dr}^{\mathrm{a}}$ Cláudia B. de C. N. Ometto.

CHARTIER, Anne-Marie. Os cadernos escolares: organizar os saberes, escrevendo-os. In: Revista de Educação Pública - v. 16 n. 32 - (set.-dez. 2007) - Cuiabá: EdUFMT, 2007. 